\title{
Importance of Biochemical Marker Genes in Inbred Strains of Mice
}

\author{
Some Problems on Checking Genetic Purity \\ of Inbred Strains \\ Michiru MIZUNO*, Kiyoshi SUZUKI**, Takeshi TOMITA***, and Kyoji KONDO*** \\ * Shizuoka Laboratory Animal Agricultural Cooperative \\ Association, Koike-cyo, 1616, Hamamatsu, 435 \\ ** Institute of Medical Science, Tokyo University, \\ Shirogane-dai, 4-6-2, Tokyo, 180 \\ *** Laboratory of Animal Genetics, Faculty of Agriculture, \\ Nago ya University, Nago ya, 464
}

(Received for publication : September 14, 1976)

\begin{abstract}
In order to check genetic purity of inbred strains of mice, we surveyed five biochemical variants in certain 69 strains, some of which had established from Japanese fancy mice. The loci examined were Hemoglobin beta-chain, Malic enzyme (supernatant form), Isocitrate dehydrogenase (supernatant form), Serum esterase-1, and Serum esterase-2. These loci were all in homozygous states as far as examined, however, some subline divergences were found in a few strains, that is to say, sublines were found to be fixed with different alleles at some loci. Importance of biochemical marker genes to check genetic purity of strains and several derived problems are mentioned.
\end{abstract}

\section{近交系マウスにおける生化学的 \\ 標識遺伝子の重要性 \\ 一一系統の遺伝的チェックの際生じた問題点 \\ 水野充*.鈴木潔**. 富田武***. 近藤恭司*** \\ $*$ 静岡実験動物農業協同組合 \\ ** 東京大学医科学研究所実験動物研究施設 \\ *** 名古屋大学農学部家畜育種学教室}

Smithies [14] により考案されたデンプンゲル電気泳 動法の発展に伴い種々の蛋白・酵素の遺伝的解析が可能 となり, house mouse (Mus musculus) においては 今日まで少なくとも 30 以上の電気泳動的に検出されらる 変異一生化学的変異 (biochemical variant) 一 報告されている。又これらのらちのいくつかの変異が既 存の系統間に存在する変異として認められ [9]（表 1), 多数の情報が得られている $[9,15]$ 。
一方実験動物の立場からは, Roderick ら [9] や水 野・近藤 [8] が示唆するよらに，毛色を支配する遺伝 子座位と共にこれら系統間変異を有する生化学的変異を 標識として, 系統の遺伝的斉一性をチエックすることが 重要であると考えられる。

我々はこのような観点からこれら系統間変異を有する いくつかの生化学的変異について，（1）既に報告されて いる系統についてはそれらのチエックを，(2）まだ報告 
Table 1. Biochemical Variants Found in Inbred Strains and Their Linkage Groups

\begin{tabular}{rlrl}
\hline $\begin{array}{c}\text { Linkage } \\
\text { Group }\end{array}$ & Locus & $\begin{array}{c}\text { Linkage } \\
\text { Group }\end{array}$ & Locus \\
\hline I & Gpi-1 & XI & Ldr-1 \\
I & Hbb & XIII & Dip-1 \\
I & Mod-2 & XIII & Id-1 \\
II & Mod-1 & XVII & Pgm-1 \\
VII & Es-3 & XVIII & Es-1 \\
VIII & Gpd-1 & XVIII & Es-2 \\
VIII & Pgm-2 & XVIII & Got-2 \\
\hline
\end{tabular}

されていない系統（主に K-group, N-group［6]など 我が国を起源としている系統）については，それらの調 查を行い，今回はこれまでに得られた調査結果と更に結 果をもとにして試みた系統チエックの問題，およびその 際得られたいくつかの問題について報告する。

生化学的標識遗伝子の選定条件

我々は生化学的標識遺伝子の条件として次の点を問題 とした。

(1) 系統間変異が適当に存在すること（たとえば lactate dehydrogenase regulaor 遺伝子座位（遺伝子座 位記号 Ldr-1，以下同様）は常染色体上の一対の対立遺 伝子である $\mathrm{Ldr}-1^{a}$ および $\mathrm{Ldr}-1^{b}$ を支配している。し かし報告されている限りでは $\mathrm{Ldr}-1^{b}$ 型の系統は稀であ ク，LP/J 系など数系統にしか観察されて扣らず $[9,12]$ これでは標識遺伝子としての効果が得られ難いため)。

（2）染色法が容易なこと（一次反応で検出される蛋白， 醅素であること)。
（3）遺伝子型が判定しやすいこと。

（4）毛色を支配する遺伝子座位（A， B， C，D，S）を 含め, なるべく異なる連関群に属していること（多くの 染色体を把握したいため)。

（5）試料にはなるべく血液（血㢡・血球）が用いられ ること（臓器を試料とする場合には対象とする動物を殺 さなくてはならないため)。

以上の諸条件を考慮し, 我々は次の 5 つの生化学的変 異を今回の調查の際に標識遺伝子として選定した。

Hemoglobin beta- chain ( $\mathrm{Hbb}$ )

Malic enzyme, supernatant form (Mod-1)

Isocitrate dehydrogenase, supernatnat form (Id-1)

Serum esterase-1 (Es-1)

Serum esterase-2 (Es-2)

これらは前述の条件を満足しているとは言えない。特 に Es-2 型変異は系統間のバラッキがあまりなく $[9$ ， 10]，標識遗伝子としての価值があまりないと考号られ たが，この Es-2 型変異は Es-1 型変異と同じ泳動像 で検出・判定ができるため標識遗伝子に加えた。

\section{材料および方法}

今回の調査対象となった系統は現在東京大学医科学研 究所実験動物研究施設で維持されている33系統, および 名古屋大学農学部で維持・育成されている36系統の52系 統，のべ69系統である。これらのなかにはまだ近交系と して確立していない系統が含まれており，これらの系統 の調査時における世代数は, Crn 系 (F16), Pink 系 (F16), Pon 系 (F17), Ponel 系 (F15), Pony 系 (F 17), SIIIb 系 (F15) および Xbi 系（F17）である。 各系統の維持集団のカナメを成す一組の交配ペアである

Table 2. Methods for Detection of Biochemical Variants

\begin{tabular}{|c|c|c|c|c|c|}
\hline Locus & Buffer System & Tissue & Substrate & Coenzyme Dye & Other \\
\hline $\mathrm{Hbb}$ & Tris-Borate $(\mathrm{pH} \mathrm{9.0)}$ & alkylated RBC & & Amido Black $10 \mathrm{~B}$ & \\
\hline Mod-1 & Tris-Citrate (pH 6.2) & Kidney & L-Malic acid & NADP NBT*, PMS** & $\mathrm{MnCl}_{2}$ \\
\hline Id-1 & Tris-Citrate (pH 7.0) & Liver & $\mathrm{Na}_{3} \cdot$ Isocitric acid & NADP NBT, PMS & $\mathrm{MnCl}_{2}$ \\
\hline Es-1 & $\begin{array}{l}\text { Tris-EDTA-Borate } \\
(\mathrm{pH} \mathrm{8.6)}\end{array}$ & Plasma & Beta-naphtylacetate & Fast Blue BB Salt & \\
\hline Es-2 & & Kidney & & & \\
\hline
\end{tabular}

* Nitro Blue Tetrazolium

** Phenazine Methosulfate 
Table 3. The Distribution of Alleles at 5 Loci in Certain 69 Strains

\begin{tabular}{|c|c|c|c|c|c|c|c|c|c|c|c|}
\hline Strain & $\cdot \mathrm{Hbb}$ & Mod-1 & Id-1 & $\mathrm{Es}-1$ & $\mathrm{Es}_{\mathbf{s}}-2$ & Strain & $\mathrm{Hbb}$ & Mod-1 & Id-1 & $\mathrm{Es}-1$ & $\mathrm{Es}-2$ \\
\hline $\mathrm{A} / \mathrm{Jms}$ & $\mathrm{d}$ & $\mathrm{a}$ & $\mathrm{a}$ & $\mathrm{b}$ & $\mathrm{b}$ & $\mathrm{KSB} / \mathrm{Nga}$ & $\mathbf{s}$ & $\mathrm{a}$ & $\mathrm{b}$ & $\mathrm{b}$ & $\mathrm{a}$ \\
\hline $\mathrm{A} / \mathrm{Nga}$ & $\mathrm{d}$ & $\mathrm{a}$ & $\mathrm{a}$ & $\mathrm{b}$ & $\mathrm{b}$ & $\mathrm{KR} / \mathrm{Nga}$ & $\mathrm{s}$ & $\mathrm{a}$ & $\mathrm{b}$ & $\mathrm{b}$ & $\mathrm{b}$ \\
\hline $\mathrm{AKR} / \mathrm{Jms}$ & $\mathrm{d}$ & $\mathrm{b}$ & $\mathrm{b}$ & $\mathrm{b}$ & $\mathrm{b}$ & $\mathrm{LP} / \mathrm{J} \#$ & $\mathrm{~d}$ & $\mathrm{a}$ & $\mathrm{a}$ & $\mathrm{b}$ & $\mathrm{b}$ \\
\hline $\mathrm{AY} / \mathrm{Nga}$ & $\mathrm{d}$ & $\mathrm{a}$ & $\mathrm{b}$ & $\mathrm{b}$ & $\mathrm{b}$ & $\mathrm{NBR} / \mathrm{Nga}$ & s & $\mathrm{a}$ & $\mathrm{b}$ & $\mathrm{b}$ & $\mathrm{b}$ \\
\hline BALB/cJms* & $\mathrm{d}$ & $\mathrm{a}$ & $\mathrm{a}$ & $\mathrm{b}$ & $\mathrm{b}$ & $\mathrm{NC} / \mathrm{Jms}$ & $\mathrm{s}$ & $\mathrm{a}$ & $\mathrm{b}$ & $\mathrm{b}$ & $\mathrm{b}$ \\
\hline BALB/cJms** & $\mathrm{d}$ & a & $\mathrm{a}$ & $\mathrm{b}$ & $\mathrm{b}$ & $\mathrm{NC} / \mathrm{Nga}$ & $\mathrm{s}$ & $\mathrm{a}$ & $\mathrm{b}$ & $\mathrm{b}$ & $\mathrm{b}$ \\
\hline $\mathrm{BALB} / \mathrm{c} \# \#$ & $\mathrm{~d}$ & $\mathrm{a}$ & $\mathrm{a}$ & $\mathrm{b}$ & $\mathrm{b}$ & $\mathrm{NZB} / \mathrm{Jms}$ & $\mathrm{d}$ & $\mathrm{b}$ & $\mathrm{a}$ & $\mathrm{a}$ & $\mathrm{b}$ \\
\hline BRSUNT/Jms & $\mathrm{d}$ & $\mathrm{b}$ & $\mathrm{b}$ & $\mathrm{b}$ & $\mathrm{b}$ & $\mathrm{NZB} / \mathrm{Nga}$ & $\mathrm{d}$ & $\mathrm{b}$ & a & & $\mathrm{b}$ \\
\hline $\mathrm{BS} / \mathrm{Nga}$ & $\mathrm{s}$ & $\mathrm{a}$ & $\mathrm{a}$ & $\mathrm{b}$ & $\mathrm{b}$ & Pink/Nga & $\mathrm{p}$ & & $\mathrm{b}$ & $\mathrm{b}$ & $\mathrm{b}$ \\
\hline $\mathrm{CBA} / \mathrm{Jms}$ & $\mathrm{d}$ & $\mathrm{b}$ & $\mathrm{b}$ & $\mathrm{b}$ & $\mathrm{b}$ & Pon/Nga & $\mathrm{p}$ & $\mathrm{a}$ & $\mathrm{a}$ & $\mathrm{a}$ & $\mathrm{b}$ \\
\hline $\mathrm{CBA} / \mathrm{Nga}$ & $\mathrm{d}$ & $\mathrm{a}$ & $\mathrm{b}$ & $\mathrm{b}$ & $\mathrm{b}$ & Ponel/Nga & $\mathrm{p}$ & $\mathrm{a}$ & $\mathrm{b}$ & $\mathrm{a}$ & $\mathrm{b}$ \\
\hline $\mathrm{CFW} / \mathrm{Jms}$ & $\mathrm{d}$ & $\mathrm{a}$ & $\mathrm{b}$ & $\mathrm{b}$ & $\mathrm{b}$ & Pony/Nga & $\mathrm{p}$ & $\mathrm{a}$ & $b$ & $\mathrm{a}$ & $\mathrm{b}$ \\
\hline $\mathrm{CF} \sharp 1 / \mathrm{Jms}$ & $\mathrm{d}$ & $\mathrm{b}$ & $\mathrm{b}$ & $\mathrm{b}$ & $\mathrm{b}$ & $\mathrm{RR} / \mathrm{Jms}$ & $\mathrm{d}$ & $\mathrm{a}$ & $\mathrm{a}$ & $\mathrm{b}$ & $\mathrm{b}$ \\
\hline $\mathrm{Crn} / \mathrm{Nga}$ & $\mathrm{s}$ & a & $\mathrm{b}$ & $\mathrm{b}$ & $\mathrm{a}$ & $\mathrm{SJL} / \mathrm{Jms}$ & $\mathrm{s}$ & $\mathrm{a}$ & $\mathrm{b}$ & $\mathrm{b}$ & $\mathrm{b}$ \\
\hline $\mathrm{CS} / \mathrm{Nga}$ & s & $\mathrm{a}$ & $\mathrm{b}$ & $\mathrm{b}$ & $\mathrm{b}$ & $\mathrm{SS} / \mathrm{Jms}$ & $\mathrm{s}$ & $\mathrm{a}$ & $\mathrm{b}$ & $\mathrm{b}$ & $\mathrm{b}$ \\
\hline $\mathrm{C} 3 \mathrm{H} / \mathrm{Jms}$ & $\mathrm{d}$ & $\mathrm{a}$ & a & $\mathrm{b}$ & $\mathrm{b}$ & $\mathrm{STR} / \mathrm{Jms}$ & $\mathrm{s}$ & $\mathrm{b}$ & $\mathrm{b}$ & $\mathrm{b}$ & $\mathrm{b}$ \\
\hline $\mathrm{C} 3 \mathrm{Hf} / \mathrm{Nga}$ & $\mathrm{d}$ & $\mathrm{a}$ & $\mathrm{a}$ & $\mathrm{b}$ & $\mathrm{b}$ & $\mathrm{SW} / \mathrm{CNga}$ & $\mathrm{d}$ & a & $\mathrm{b}$ & $\mathrm{b}$ & $\mathrm{b}$ \\
\hline $\mathrm{C} 57 \mathrm{BL} / 6 \mathrm{Jms}$ & $\mathrm{s}$ & $b$ & $\mathrm{a}$ & $\mathrm{a}$ & $\mathrm{b}$ & $\mathrm{SII} / \mathrm{Jms}$ & $\mathrm{s}$ & $\mathrm{a}$ & $\mathrm{b}$ & $\mathrm{b}$ & $\mathrm{a}$ \\
\hline C57BL/Nga & $\mathrm{s}$ & $\mathrm{b}$ & $\mathrm{a}$ & $\mathrm{a}$ & $\mathrm{b}$ & SIIT/Nga & $\mathrm{s}$ & $\mathrm{a}$ & $\mathrm{b}$ & $\mathrm{b}$ & $\mathrm{a}$ \\
\hline C57BL/10Sn \# & $\mathrm{s}$ & $\mathrm{b}$ & $\mathrm{a}$ & $\mathrm{a}$ & $\mathrm{b}$ & SIIIb/Nga & $\mathrm{s}$ & & $\mathrm{a}$ & $\mathrm{a}$ & $\mathrm{b}$ \\
\hline $\mathrm{C} 57 \mathrm{~L} / \mathrm{Jms}$ & $\mathrm{s}$ & $\mathrm{b}$ & $\mathrm{b}$ & $\mathrm{a}$ & $\mathrm{b}$ & $\mathrm{WHT} / \mathrm{Ht} \#$ & $\mathrm{~s}$ & $\mathrm{a}$ & $\mathrm{a}$ & $\mathrm{b}$ & $\mathrm{b}$ \\
\hline $\mathrm{C} 57 \mathrm{~L} / \mathrm{Nga}$ & $\mathrm{s}$ & $\mathrm{a}$ & $\mathrm{b}$ & $\mathrm{a}$ & $\mathrm{b}$ & WN/Nga & $\mathrm{s}$ & $\mathrm{b}$ & $\mathrm{a}$ & $\mathrm{a}$ & $\mathrm{b}$ \\
\hline $\mathrm{DBA} / \mathrm{Jms}$ & $\mathrm{d}$ & $\mathrm{a}$ & $\mathrm{b}$ & $\mathrm{b}$ & $\mathrm{b}$ & $\mathrm{Xbi} / \mathrm{Nga}$ & $\mathrm{s}$ & $\mathrm{b}$ & $\mathrm{a}$ & $\mathrm{a}$ & $\mathrm{b}$ \\
\hline $\mathrm{DBA} / 1 \mathrm{Jms}$ & $\mathrm{d}$ & $\mathrm{a}$ & $\mathrm{b}$ & $\mathrm{b}$ & $\mathrm{b}$ & $129 / \mathrm{J} \#$ & $\mathrm{~d}$ & $\mathrm{a}$ & $\mathrm{a}$ & $\mathrm{b}$ & $\mathrm{b}$ \\
\hline $\mathrm{DBA} / 1 \mathrm{~J} \#$ & $\mathrm{~d}$ & $\mathrm{a}$ & $\mathrm{b}$ & $\mathrm{b}$ & $\mathrm{b}$ & $129 / \operatorname{Re} \#$ & $\mathrm{~d}$ & $\mathrm{a}$ & $\mathrm{a}$ & $\mathrm{b}$ & $\mathrm{b}$ \\
\hline $\mathrm{DBA} / 2 \mathrm{Jms}$ & $\mathrm{d}$ & $\mathrm{a}$ & $\mathrm{b}$ & $\mathrm{b}$ & $\mathrm{b}$ & I-TES/Nga & $\mathbf{s}$ & $\mathrm{a}$ & $\mathrm{b}$ & $\mathrm{b}$ & $\mathrm{a}$ \\
\hline $\mathrm{DBA} / 2 \mathrm{Nga}$ & $\mathrm{d}$ & $\mathrm{a}$ & $\mathrm{b}$ & $\mathrm{b}$ & $\mathrm{b}$ & II-TES/Nga & $\mathrm{s}$ & a & $\mathrm{b}$ & $\mathrm{b}$ & $\mathrm{b}$ \\
\hline $\mathrm{DCR} / \mathrm{CNga}$ & $\mathrm{s}$ & $\mathrm{a}$ & $\mathrm{b}$ & $\mathrm{b}$ & $\mathrm{b}$ & $\mathrm{IX}-\mathrm{BL} / \mathrm{Nga}$ & $\mathrm{s}$ & $\mathrm{a}$ & a & $\mathrm{b}$ & $\mathrm{b}$ \\
\hline $\mathrm{DDD} / \mathrm{Jms}$ & s & $\mathrm{a}$ & $\mathrm{b}$ & $\mathrm{b}$ & $\mathrm{b}$ & $\mathrm{IX}-\mathrm{BL}-\mathrm{at} / \mathrm{Nga}$ & $\mathbf{s}$ & $\mathrm{a}$ & $\mathrm{a}$ & $\mathrm{b}$ & $\mathrm{b}$ \\
\hline $\mathrm{DDK} / \mathrm{Nga}$ & $\mathrm{s}$ & $\mathrm{a}$ & $\mathrm{a}$ & $\mathrm{b}$ & $\mathrm{b}$ & 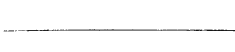 & 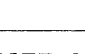 & & & & \\
\hline $\mathrm{FM} / \mathrm{Jms}$ & $\mathrm{d}$ & a & $\mathrm{b}$ & $\mathrm{b}$ & $\mathrm{b}$ & \multirow{10}{*}{\multicolumn{6}{|c|}{$\begin{array}{l}\text { Es-1 locus of NZB/Nga was found to be } \\
\text { heterozygous. } \\
\text { Details are shown in the paper of Mizuno } \\
\text { and Kondo (1976). } \\
\text { * from Simonsen Laboratories, Inc. } \\
\text { ** from Sloan-Kettering Institute } \\
\text { \# maintained by Institute of Medical Science } \\
\# \text { maintained byNagoya University }\end{array}$}} \\
\hline $\mathrm{HTH} / \mathrm{Jms}$ & $\mathrm{s}$ & $\mathrm{b}$ & a & $\mathrm{b}$ & b & & & & & & \\
\hline $\mathrm{HTH} / \mathrm{Nga}$ & $\mathrm{s}$ & $\mathrm{b}$ & a & $\mathrm{b}$ & $\mathrm{b}$ & & & & & & \\
\hline HTI/Jms & $\mathrm{s}$ & $\mathrm{b}$ & $\mathrm{a}$ & $\mathrm{a}$ & $\mathrm{b}$ & & & & & & \\
\hline $\mathrm{HTI} / \mathrm{Nga}$ & $\mathrm{s}$ & $\mathrm{b}$ & $\mathrm{a}$ & $\mathrm{a}$ & $\mathrm{b}$ & & & & & & \\
\hline $\mathrm{HR} / \mathrm{Jms}$ & $\mathrm{d}$ & a & $\mathrm{a}$ & $\mathrm{b}$ & $\mathrm{b}$ & & & & & & \\
\hline IMV/Nga & $\mathrm{d}$ & $\mathrm{a}$ & $\mathrm{b}$ & $\mathrm{b}$ & $\mathrm{b}$ & & & & & & \\
\hline $\mathrm{KK} / \mathrm{Jms}$ & $\mathrm{s}$ & $\mathrm{a}$ & $\mathrm{a}$ & $\mathrm{b}$ & $\mathrm{a}$ & & & & & & \\
\hline $\mathrm{KK} / \mathrm{Nga}$ & $\mathrm{s}$ & $\mathrm{a}$ & $\mathrm{a}$ & $\mathrm{b}$ & a & & & & & & \\
\hline $\mathrm{KOMA} / \mathrm{Jms}$ & $\mathrm{s}$ & $\mathrm{a}$ & $\mathrm{a}$ & $\mathrm{b}$ & $\mathrm{b}$ & & & & & & \\
\hline
\end{tabular}


雌雄各一匹づつを試料に供した。

方法にはデンプンゲルを支持体とした水平電気泳動法 を用い, 更に各々の蛋白酵素に特異的な組織化学反応に より各生化学的変異の遺伝子型を判定した。泳動条件お よび染色法は, Hbb 型変異には Hutton [2], Mod-1 型変異には Chapman 5 [1] の变法, Id-1 型変異に は Shaw and Prasad [11], Es-1 型および Es-2 型 の各変異には Ruddle ら [10］の変法をそれぞれ用い た。なおこれらの方法の詳細を表 2 に示す。

今回選んだ標識遺伝子に関し，C $57 \mathrm{BL} / 6 \mathrm{~J}$ 系および $\mathrm{DBA} / 2$ 系両系統の遺伝子型は下記のようになっており， [9]，Es-2 遺伝子座位を除く他の 4 遺伝子座位が互いに 対立する遺伝子に固定しているため, 今回の調査におい てはこれら両系統を比較対照の基準とした。

\begin{tabular}{|c|c|c|c|c|}
\hline $\mathrm{C} 57 \mathrm{BL} / 6 \mathrm{~J}$ & $\mathrm{Hbb}^{s}$ & Mod-1 ${ }^{b}$ & $\mathrm{Id}-1^{a}$ & Es-1 \\
\hline $\mathrm{DBA} / 2$ & $\mathrm{Hbb}^{d}$ & Mod-1 ${ }^{a}$ & Id $-1^{b}$ & Es-1 \\
\hline
\end{tabular}

又 $\mathrm{Hbb}^{p}$ はPink 系 (この Pink 系の $\mathrm{Hbb}^{p}$ につ いては後に $\mathrm{AU} / \mathrm{J}$ 系 [9] で同定した）を， Es-2a は $\mathrm{KK}$ 系をそれぞれ基準とした。なお本調査は 1974 年 9 月より 1976 年 3 月にかけて行われた。

\section{成績および考察}

得られた泳動像を図 1-4 亿, 調査結果を表 3 に示す。 表 3 の配列は縦に系統を, 横に遺伝子座位を取ってあ る。系統はアルファベット順に掲げ, 調査対象となった 両維持機関で重複する系統も省略せずに示した。

今回の調査より我が国を起源とする系統の生化学的変 異が総合的に明記された。材料および方法の項で示した 近交系育成途中の 7 系統に関して調査された遺伝子座位 は既に固定していることが判明した。更に当然ではある が前回報告した NZB 系の Es-1 遗伝子座位以外の調 查個体に打ける遺伝子座位はすべて固定していた。

次に $\mathrm{A}$ 系, $\mathrm{KK}$ 系など医科学研究所・名古屋大学農 学部の両機関で維持されており, しかも既に亜系として 確立している系統の遺伝子組成の比較, あるいは既に報 告のある同一名の系統との比較を行った場合, NZB 系 を含む次の 3 系統では一部の遺伝子座位がそれぞれ異な った対立遺伝子に固定していることが発見された(表 4)。 すなわち CBA 系に関して CBA/J 系は Mod-1 遺伝 子座位および今回の調査には加えなかったが Ldr-1 遺 伝子座位がそれぞれ Mod-1 ${ }^{b}$ および Ldr-1 ${ }^{a}$ である [9]のに対し，CBA/Jms 系 (Sweden の Karolinska 研究所由来) は Mod-1 $1^{b}$ および Ldr-1 $1^{b}, \mathrm{CBA} / \mathrm{Nga}$ 系
Table 4. Strains Found to be Fixed with Different Alleles

\begin{tabular}{|c|c|}
\hline Strain & Allele \\
\hline $\mathrm{CBA} / \mathrm{Jms}$ & Mod- $1^{b}, \operatorname{Ldr}-1^{b}$ \\
\hline $\mathrm{CBA} / \mathrm{Nga}$ & $\operatorname{Mod}-1^{a}, \operatorname{Ldr}-1^{a}$ \\
\hline $\mathrm{CBA} / \mathrm{J}^{*}$ & Mod- $1^{b}, \operatorname{Ldr}-1^{a}$ \\
\hline CBA/Lon** & $-\quad \mathrm{Ldr}-1^{\mathrm{b}}$ \\
\hline $\mathrm{C} 57 \mathrm{~L} / \mathrm{Jms}$ & Mod- $1^{b}$ \\
\hline $\mathrm{C} 57 \mathrm{~L} / \mathrm{Nga}$ & Mod-1a \\
\hline $\mathrm{NZB} / \mathrm{Jms}$ \# & $E s-1^{a}$ \\
\hline $\mathrm{NZB} / \mathrm{Nga} \#$ & Heterozygous \\
\hline $\mathrm{NZB} / \mathrm{Hz}^{*}$ & $\mathrm{Es}-1^{b}$ \\
\hline
\end{tabular}

* Roderick et. al., (1971)

** Martin and Petras (1971)

\# Mizuno and Kondo (1976)

（国立遺伝学研究所由来）は Mod-1 ${ }^{a}$ および Ldr-1 ${ }^{a}$ にそれぞれ固定していることが判明した。これら 3 亚系 について他の 4 遺伝子座位 (Hbb, Id-1, Es-1, Es-2) がすべて一致していること，Mod-1 遺伝子座位と連関 している Serum transferrin（Trf）遺伝位座位 $[3$, 13]が, CBA/Jms 系と CBA/Nga 系の両系統とも $\operatorname{Trf}^{a}$ に固定しており Shreffler の報告 [13]と一致し ていることから，上記の原因として単純な交配ミスとは 考えられない。又 CBA/Lon 系が Ldr-1 ${ }^{b}$ であるとい う報告 [7] もあることから，この原因としてこれら両 遺伝子座位がまだ均一になっていない段階で他の機関へ 譲渡された後，それぞれ対立する遺伝子に固定した可能 性が強いと思われる。同様のことが C57L 系の Mod-1 遺伝子座位にも観察され，C57L/Jms 系 (Swedenの Karolinska) 研究所由来は Mod-1 ${ }^{b}$, C 57 L/Nga 系 （国立遺伝学研究所由来）は Mod-1 ${ }^{a}$ であった。この ような例は著者の前回の報告 [8] にもあるように, NZ B 系の Es-1 遺伝子座位にも観察されており，前回の 報告にも述べたようにこれらの事柄は実験動物を利用す る立場から見れば，異なる機関，研究所で維持されてい る同一名の系統を遺伝的に同一視して良いか否かという 問題を提起していると考えられる。

今回の調査対象となった系統を近藤 $[4]$ に従い，その 起源により分類すれば次のよらになる。

(1) KK，NC など我が国では古くから愛玩動物とし て維持されているマウスを起源としている系統

(2) BALB/c，CBA，C3H のように戦後主にアメリ 
(1)

(2)

(3)

(4)

(5)

(6)

(7)

(8)

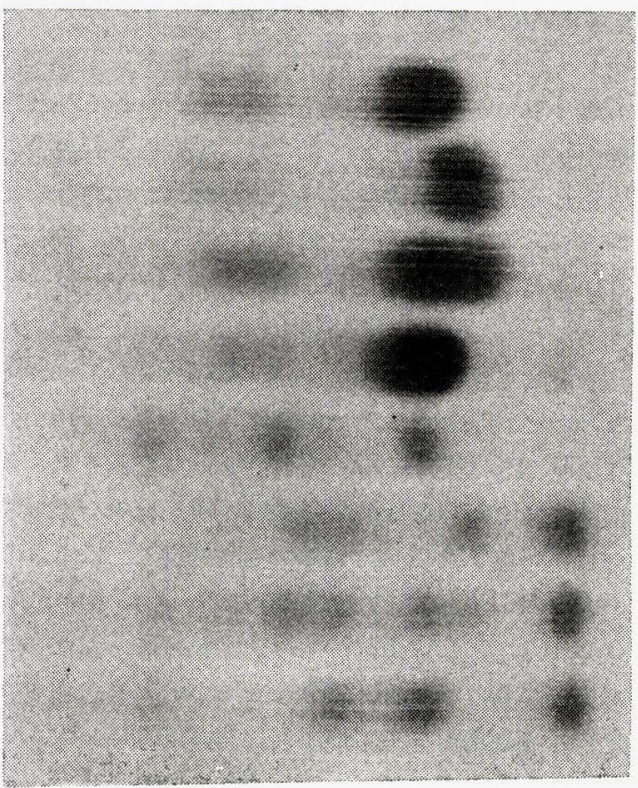

Fig. 1. Plasma (channels 1-4) and kidney (channels 5-8) esterase zymograms using beta-naphtylacetate as a substrate. Mice and their esterase (Es-1 and Es-2) genotypes are follows.

Channels (1) and (5); SII, Es-1 ${ }^{b} / \mathrm{Es}-1^{b}, \mathrm{Es}-2^{a} / \mathrm{Es}-a$.

Channels (2) and (6); C57BL/10, Es- $1^{a} / \mathrm{Es}-1^{a}$, Es$2^{b} / \mathrm{Es}-2^{b}$.

Channels (3) and (7); (SII $\times$ C57BL/10) $\mathrm{F}_{1}$, Es- $1^{a} / \mathrm{Es}-1^{b}, \mathrm{Es}-2^{a} / \mathrm{Es}-2^{b}$.

Channels (4) and (8); DBA/2, Es- $1^{b} / \mathrm{Es}_{\mathrm{s}} 1^{b}, \mathrm{Es}-2^{b} /$ Es- $2^{b}$.

\section{カから導入された系統}

（3）ドイッマウスと呼ばれており，明治以後輸入され て広く医学界で用いられているconventional mice. 系 統化されたものもある。

(4) 異なる起源の系統の交雑により育成された系統

および今回の調査対象となった系統は属していないが,

(5) 日本の野生マウス (Mus musculus molossinius）から育成された系統

この分類に従い今回の調查結果から得られた遺伝子分 布を対応させてみると, 次のよらな興味ある知見が得ら れた。すなわち，(1)のカテゴリーに属する系統群の $\mathrm{Hbb}$ 遗伝子座位がすべて $\mathrm{Hbb}^{8}$ に固定しており，C57 祖先 の系統を除く(2)の系統群は $\mathrm{Hbb}^{d}$ に固定している。更 に(2)の系統群には見られない Es-2 $2^{a}$ が(1)の系統群の K
(1)

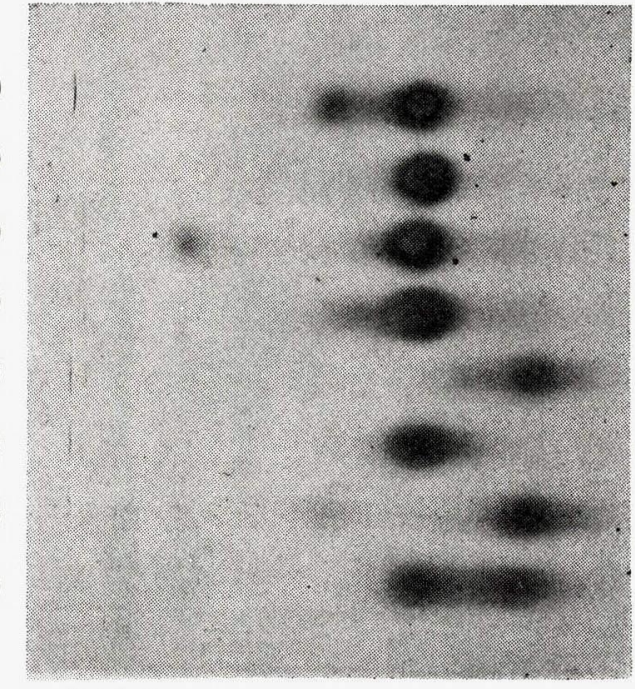

$\uparrow$ origin

Fig. 2. Zymogram of Hemoglobin beta-chain (Hbb). The lower 4 samples are alkylated with iodoacetate and the upper 4 are untreated. Mice and their Hbb genotypes are follows.

Channels (1) and (5); $\mathrm{DBA} / 2, \mathrm{Hbb}^{d} / \mathrm{Hbb}^{d}$.

Channels (2) and (6); $\mathrm{C} 57 \mathrm{BL} / 6, \mathrm{Hbb}^{s} / \mathrm{Hbb}^{s}$.

Channels (3) and (7); Pink/Nga, $\mathrm{Hbb}^{p} / \mathrm{HHbb}^{p}$.

Channels (4) and (8); (C57BL/10 $\times \mathrm{DBA} / 2) \mathrm{F}_{1}$, $\mathrm{Hbb}^{s} / \mathrm{Hbb}^{d}$.

(1)

(2)

(3)

(4)

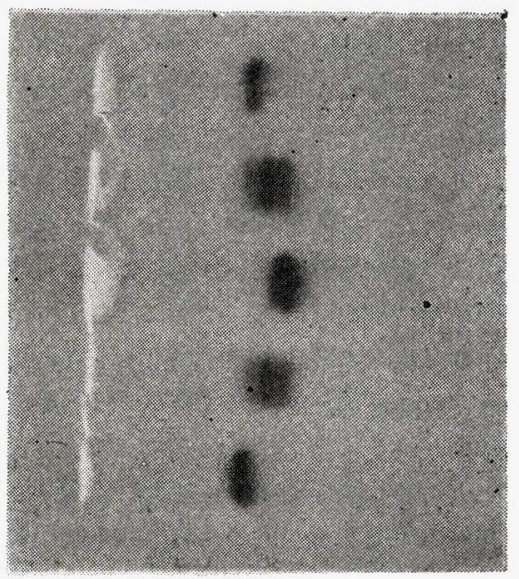

\section{$\uparrow$ origin}

Fig. 3. Zymogram of Isocitrate dehydrogenase, supernatant form (Id-1). Mice and their Id-1 genotypes are follows.

Channels (1) and (5); C57BL/6, Id- $1^{a} / \mathrm{Id}-1^{a}$.

Channels (2) and (4); (C57BL/6 $\times$ DBA/2) $\mathrm{F}_{1}$, Id $-1^{a} / \mathrm{Id}-1^{b}$

Channel (3) ; DBA/2, Id-1 $b /$ Id- $1^{b}$. 
(1)

(2)

(3)

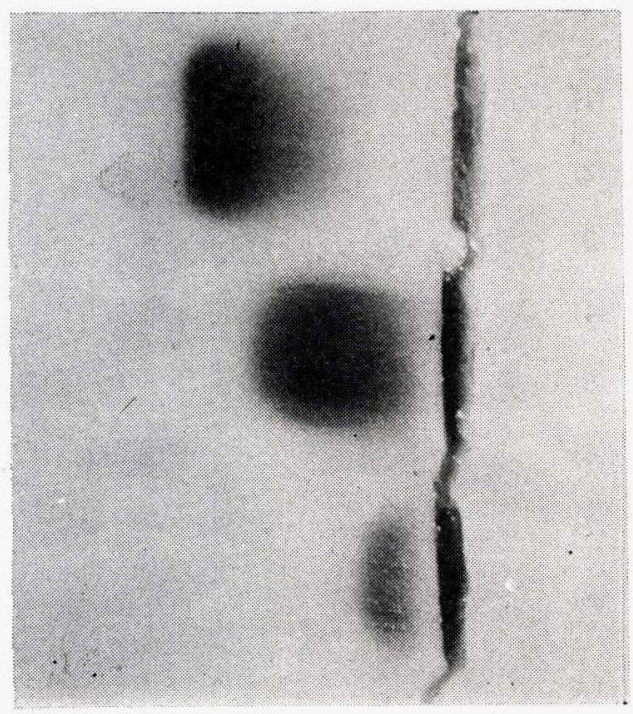

$\uparrow$ origin

Fig. 4. Zymogram of Malic enzyme, supernatant form (Mod-1). Mice andtheir Mod-1 genotypes are follows.

Channel (1); C57BL/6, Mod-1 ${ }^{b} /$ Mod- $-1^{b}$.

Channel (2);(C57BL/6 $\times \mathrm{DBA} / 2) \mathrm{F}_{1}$, Mod $-1 a / \operatorname{Mod}-1^{b}$.

Channel (3) ; DBA/2, Mod-1 ${ }^{a} / \operatorname{Mod}-1^{a}$.

K, KSB などの系統に認められた。同じく Pink 系お よび Pink 系と他系統との交雑により育成された Pon, Pony などの系統が $\mathrm{Hbb}^{p}$ に固定しており, 他系統に 比ベュニークな存在であることが判明した。なお Pink 系は(5)のカテゴリーに属する野生マウスとの交雑があっ たと思われるマウスを起源としている系統である。この ほかには顕著な特徵は見られないが, 特に $\mathrm{Hbb}$ 遺伝子 と起源の対応が明確に見いだされたことは，へモグロビ ンの生理機能との関連を暗示するかも知れない。

どのような原因であれ，系統の遗伝的組成が変化する 危険性はないとは言えず，かりにこのような事態が生じ たとしてもこれを早期に発見できれば混乱は最少限にお さえられる筈である。そのためには常時系統の遺伝的子 エックが必要であろう。それゆえ今回の標識とした $\mathrm{Hb}$ b, Mod-1, Id-1, Es-1, Es-2 の各遺伝子座位と毛色を 支配する遺伝子座位 (A, B, C, D, S) の合計10遗伝子 座位を用いた系統の遺伝的チエックの問題について多少 の考察を加える。

本調査では $\mathrm{AY}, \mathrm{KK}$ などの系統がこれら 10 遺伝子 座位に関してユニークなパターンを示した。この意味で
はこれらの系統のチエックは可能となるわけである。し かしこれは調查した系統の範囲内で論ずる場合であり， 必ずしも絶対的といらわけではない。しかしこれら10遗 伝子座位のチエックを行うことによりある程度の効果は 得られるものと期待される。これに反し, 異なる系統が 同一のパターンを示した例も見られ，表 3 に見られるよ らにA系および $\mathrm{BALB} / \mathrm{c}$ 系ではいられれアルビノ( -cc- — $, \mathrm{Hbb}^{d}, \mathrm{Mod}-1^{a}, \mathrm{Id}-1^{a}, \mathrm{Es}-1^{b}, \mathrm{Es}-2^{b}$ のパ ターンを, C $57 \mathrm{BL} / 6$ 系・C $57 \mathrm{BL} / 10$ 系および HTI 系 ではいづれもブラック (aaBBCCDDSS), $\mathrm{Hbb}^{s}, \mathrm{Mod}$ $-1^{b}, \mathrm{Id}-1^{a}, \mathrm{Es}-1^{a}, \mathrm{Es}-2^{b}$ のパターンを示した。現在の 段階ではこれら系統間での交雑が生じた場合にはチエッ クは不可能となるが, 前者の例では更に Tester 系 (a abbCCddss) [5] と交配すれば，A 系 (aabbcc) と $\mathrm{BALB} / \mathrm{c}$ 系 (AAbbcc) の区別が可能となり両系統間 の交雑の有無の判断は容易になる。しかしこの場合でも 検定する動物が交配可能でなければならず, しかも後代 検定によるといら煩しさを持つことは言うまでもない。 このような系統についてチエックを容易にするためには 生化学的標識遺伝子の数を増やすか, あるいは $\mathrm{H}-2$ 遗 伝子座位のような他の標識遺伝子を導入する必要がある と考えられる。

いづれにせよ系統の維持, 生産の段階で同じ毛色を有 する系統，特にアルビノの系統同志の交雑があった場合 や，不可視的な突然変異が生じたりした場合は現場で判 断することは不可能である。このような事態を見のがす ことにより系統を用いた動物実験に重大な誤ちを犯すこ とのないように, これらの系統を同じ室で維持しないと いった面での配虑が必要であろう。しかし我が国の現状 では実行することは不可能に近く, この点からも生化学 的標識遺伝子を用いた系統の遺伝的チエックを行らこと は重要であろう。又生化学的標識遺伝子は老令マウスを 試料とした場合でも十分に調查可能であり, しかも遺伝 子座位の大部分が共優性を示すため, 遺伝子型が直接判 定できるといら長所を持つ。生化学的変異を支巶する遗 伝子座位が多数知られていることも有利な条件のひとつ である。

このような遺伝的チエックが日常化され, その際ある 系統に従来持っていた遺伝子と異なる遺伝子が出現した 場合，他の標識遺伝子を総合的に検討することによりそ の異なった遺伝子が交配ミスによるものか, 突然変買に よるものかの判断を容易にするであろう。 
要 約

東京大学医科学研究所拉よび名古屋大学農学部で維持 されている系統の生化学的標識遺伝子 (Hbb, Mod-1, Id-1, Es-1, Es-2) の調査を行い,

(1) CBA 系の Mod-1 遺伝子坐位および今回の調查 には加えなかったが $\mathrm{Ldr}-1$ 遺伝子座位, C $57 \mathrm{~L}$ 系の Mod-1 遉伝子座位がそれぞれ黑なった対立頲伝子に固 定している亜系の存在することが明らかになった。

（2）我が国を起源とする系統と，戦後外国より輸入さ れた系統について, 特に $\mathrm{Hbb}$ 運伝子座位に顕著な差が 見られた。

（3）交配ミスや突然変異による系統の遺伝子組成の娑 化を早期に発見するため,これらの生化学的㯲識辺伝子 を用いて系統の遺伝的チエックを行らことの重要性を小 唆し, チエックの際の閏題点について多少の考察を加え た。

\section{文献}

[1] Chapman, V, M., Ruddle, F. H., and Roderick, T. H. (1971). Linkage of Isozyme Loci in the Mouse: Phosphoglucomutase-2 (Pg. $\mathrm{m}-2)$, Mitochondrial NADP Malate Dehydrogenase-2 (Mod-2), and Dipeptidase-1 (Dip-1). Biochem. Genet., 5, 101-110.

[2] Hutton, J. J. (1969). Linkage Analyses Using Biochemical Variants in Mice. I. Linkage of the Hemoglobin Beta-Chain and Glucosephosphate Isomerase Loci. Biochem. Genet., 3, 507-515.

[3] Hutton, J. J., and Roderick, T. H. (1970). Linkage Analyses Using Biochemical Variants in Mice. III. Linkage relationships of Eleven Biochemical Markers. Biochem. Genet., 4, 339-350.

[4] Kondo, K. (1971). Improvement and Establishment of Inbred Mouse Strain in Japan. Exp. Animals, 22 Suppl., 271-276

［5］近藤恭司・江崎孝三郎(1961), マウスの毛色遺伝
子に対するテスター系統の育成，実験動物，11， 194-196.

［6］近藤恭司・野沢謙 - 富田武 - 江崎孝三郎 (1957). 日本在来マウスから育成した系統，実験動物，6， 107-112.

[7] Martin, J. E., and Petras, M. L. (1971). Two erythrocytic lactate dehydrogenase variants in the house mouse, Mus musculus. Anim. Blood Grps Biochem. Genet., 2, 229-237.

[8] 水野充・近藤恭司(1976). NZB 系マウスの Es-1 遺伝子座位に見られた多型性の研究。実験動物, 25, 291-295.

[9] Roderick, T. H., Ruddle, F. H., Chapman, V. M., and Shows, T. B. (1971). Biochemical Polymorphisms in Feral and Inbred Mice (Mus musculus). Biochem. Genet., 5, 457466.

[10] Ruddle, F. H., Shows, T. B., and Roderick, T. H. : Esterase Genetics in Mus musculus (1969). Expression, Linkage, and Polymorphism of Locus Es-2. Genet., 62, 399-399

[11] Shaw, C. R., and Prasad, R. (1970). Starch Gel Electrophoresis of Enzymes — A Compilation of Recipes. Biochem. Genet., 4, 297-320.

[12] Shows, T. B., and Ruddle, F. H. (1968). Function of the Lactate Dehydrogenase B Gene in Mouse Erythrocytes. Evidence for Control by a Regulatory Gene. Proc. N. A. S., 61, 574-581.

[13] Shreffler, D. C. (1963). Linkage of the Mouse Transferrin Locus. J. Hered., 54, 127-129.

[14] Smithies, O. (1953). Zone Electrophoresis in Starch Gels. Group variations in the serum proteins of normal human adults. Biochem. J., 61, 629-641.

[15] Sttats, J. (1972). Standarized Nomenclature for Inbred Strains of Mice : Fifth Listing. Cancer Res., 32, 1609-1646. 